\title{
DIVERSIFIKASI KURIKULUM DALAM KERANGKA DESENTRALISASI PENDIDIKAN
}

\section{CURRICULUM DIVERSIFICATION IN THE FRAMEWORK OF EDUCATION DECENTRALIZATION}

\author{
Sutjipto \\ Pusat Kurikulum dan Perbukuan, Balitbang, Kemdikbud \\ Jl. Gunung Sahari Raya, Nomor 4A, Jakarta Pusat. \\ e-mail: sutjipto.55@gmail.com
}

Naskah diterima tanggal: 22/02/2015, Direvisi akhir tanggal: 25/10/2015, disetujui tanggal: 10/12/2015

\begin{abstract}
The purpose of this article is to examine curriculum development in the context of decentralized education governance. The results of the study show that, firstly, the legislation in effect contains provisions that make it possible for each district/region to play a role in developing curriculum tailored to the characteristics, needs and potential of each district/region. Second, diversifying and customizing curriculum content can begin with the formation of ideas and designs as well as the implementation and evaluation of the existing curriculum. Alterations made to curriculum content can range in scope from the structuring of the curriculum, the selection of essential study materials or the elaboration upon the existing standard. Third, there needs to be a change in the understanding of curriculum diversification and development. Such development should be understood as intricate work that requires professionals and experts to work together as a team to be more adequate, efficient and effective. Fourth, in terms of human resources, regional areas in Indonesia are considered to have people who are experienced in developing and customizing curriculum. Fifth, diversification of the curriculum still requires a variety of regulations to form a basis from which the development team can carry out its duties. It can be concluded that policy that facilitates the customization of the curriculum has been enacted to encourage diversity, which evolves continuously without disregarding national education goals.
\end{abstract}

Keywords: curriculum diversification, regulations, curiculum developers, education decentralisations

Abstrak: Tujuan artikel ini untuk mengkaji khasanah pengembangan diversifikasi kurikulum ditinjau dari domain desentralisasi pendidikan. Hasil kajian menunjukkan bahwa pertama, dari sisi peraturan perundang-undangan yang berlaku terdapat ketentuan yang mengikat semua pihak bahwa daerah dimungkinkan dapat berperan dalam pengembangan diversifikasi kurikulum yang disesuaikan dengan karakteristik, kebutuhan dan potensinya. Kedua, konten diversifikasi kurikulum dapat dimulai dari ide, perancangan, implementasi dan evaluasi kurikulum yang cakupannya mulai dari penataan struktur, pemilihan bahan kajian yang esensial baik secara utuh maupun merupakan penjabaran dari standar yang ada. Ketiga, dengan memandang bidang pekerjaan pengembangan diversifikasi kurikulum sebagai wilayah garapan yang tidak sederhana diperlukan tenaga pengembang yang profesional, yang berarti tim tidak mungkin bekerja sendiri agar tugas-tugas tim menjadi lebih memadai, efisien, dan efektif. Keempat, dari kesiapan sumber daya manusia daerah dianggap cukup berpengalaman dalam mengembangkan diversifikasi kurikulum. Kelima, bahwa diversifikasi kurikulum masih memerlukan beragam regulasi sebagai dasar bagi tim pengembang untuk melaksanakan tugasnya. Dengan demikian dapat disimpulkan bahwa diversifikasi kurikulum 
merupakan kebijakan yang telah diberlakukan untuk mendorong keberagaman berkembang secara terus menerus tanpa menafikan tujuan pendidikan nasional.

Kata kunci: diversifikasi kurikulum, regulasi, pengembang kurikulum, desentralisasi pendidikan

\section{PENDAHULUAN}

Wilayah Nusantara yang membentang dari Sumatera sampai Papua seluas 1,904,569 km2 dengan $4,85 \%$ merupakan perairan, memiliki sebanyak 17.504 pulau ( 7.870 pulau yang bernama), terdapat lebih dari 1.340 suku bangsa yang menggunakan lebih dari 721 bahasa daerah (Kementerian Dalam Negeri Republik Indonesia). Indonesia memiliki banyak sekali produk seni baik tradisional maupun moderen, kaya akan hasil pertanian, mempunyai beragam produk budaya melalui partisipasi ekonomi, layanan publik, pengembangan sektor pendidikan, penelitian dan pengembangan varietas unggul, daya kreatif, kerja produktif, yang dapat memperbaiki penghidupan masyarakat. Sifat kemajemukan yang dimiliki bangsa Indonesia tersebut semakin menjadi kebanggaan apabila dimanfaatkan sebaik-baiknya untuk memajukan pendidikan di daerah yang berdimensi keberagaman terkait dengan kehidupan individual, masyarakat, bangsa dan negara serta peradaban umat manusia.

Potensi sumber daya yang melimpah tersebut, apabila dikelola dan dikembangkan ke dalam diversifikasi kurikulum sekolah akan mampu meningkatkan kualitas pendidikan di daerah. Pengembangan diversifikasi kurikulum dengan materi disesuaikan dengan potensi dan karakteristik serta kebutuhan daerah akan menggali berbagai ragam potensi kearifan daerah dan keunggulan daerah yang juga akan menyemai tumbuh kembangnya baik budaya, ekonomi, pertanian, budi daya, jasa maupun kemaritiman sebagai dampak dari pembelajaran kepada peserta didik. Dilihat dari sudut pandang pengembangan kurikulum sejak proklamasi Kemerdekaan Republik Indonesia tahun 1945 hingga tahun 2015, telah diterapkan sebanyak 13 model kurikulum sekolah. Model kurikulum tersebut semuanya selalu dirancang dari pemerintah pusat. Padahal, dalam peraturan perundang-undangan di samping kurikulum diartikan sebagai seperangkat rencana dan pengaturan mengenai tujuan, isi, dan bahan pelajaran serta cara yang digunakan sebagai pedoman penyelenggaraan kegiatan pembelajaran untuk mencapai tujuan pendidikan tertentu, juga dapat disesuikan dengan kekhasan daerah (Republik Indonesia, 2003).

Secara eksplisit pengembangan diversifikasi kurikulum yang materinya disesuaikan dengan potensi dan karakteristik daerah serta kebutuhan peserta didik telah diamanatkan dalam UURI Nomor 20 Tahun 2003 tentang Sistem Pendidikan Nasional (Sisdiknas) termaktub pada Pasal 36, Ayat (2) yang berbunyi kurikulum pada semua jenjang dan jenis pendidikan dikembangkan dengan prinsip diversifikasi sesuai dengan satuan pendidikan, potensi daerah, dan peserta didik (Republik Indonesia, 2003). Prinsip ini dapat dikatakan bahwa kegiatan pembelajaran yang ada dalam diversifikasi kurikulum pada dasarnya dirancang agar bahan kajian tersebut mampu memberikan bekal pengetahuan, keterampilan dan perilaku bagi peserta didik sehingga peserta didik memiliki wawasan yang mantap tentang keadaan lingkungan dan kebutuhan masyarakat sesuai dengan norma, nilai-nilai, dan tata aturan yang berlaku di daerahnya dan sekaligus mendukung kelangsungan pembangunan daerah serta pembangunan nasional.

Pengembangan diversifikasi kurikulum di suatu daerah merupakan hal yang perlu dipikirkan untuk kemajuan daerah bersangkutan. Ke depan, diversifikasi kurikulum yang dikembangkan di daerah terutama untuk menjawab tantangan dan dinamika perubahan sesuai dengan perkembangan dan kebutuhan masya- 
rakat pada daerah bersangkutan sebagai koridor penerapan otonomi pendidikan. Otonomi pendidikan merupakan dampak dari otonomi daerah, yang berimplikasi bahwa peran dan tanggung jawab pelaksanaan pendidikan telah diserahkan kepada pemerintah daerah, termasuk tanggung jawab dalam meningkatkan mutu pendidikan (Isjoni, 2006). Mutu pendidikan yang dimaksud dapat berkait dengan kebijakankebijakan, seperti organisasi dan pembelajaran, manajemen guru, struktur dan perencanaan, dan sumber-sumber pendanaan serta pengembangan diversifikasi kurikulum daerah.

Dalam konteks sumber daya manusia (SDM) pengembang diversifikasi kurikulum, di setiap daerah umumnya telah memiliki tenaga cukup profesional. Kelompok tersebut dikenal dengan sebutan tim pengembang kurikulum (TPK) daerah. Keberadaan TPK sejak era tahun 1990an telah melalui pembinaan yang cukup intensif dan terlibat pada kegiatan yang beragam, seperti melalui bimbingan teknis dan bantuan teknis, pendampingan, dan bentuk lainnya dari pemerintah. Di samping itu, forum profesi tertentu seperti KKG, MGMP, MK3S, forum pengawas selama ini juga memperoleh pencerahan dan pelatihan bagaimana mengembangkan sebuah kurikulum. Demikian pula pengalaman pengimplementasian standar isi (SI) pada tahun 2005, misalnya yang terkenal dengan Kurikulum Tingkat Satuan Pendidikan (KTSP) juga memberi gambaran modal dasar, bahwa daerah siap untuk mengembangkan diversifikasi kurikulum secara mandiri.

Namun demikian, sejak diterapkannya peraturan perundang-undangan yang berimbas pada otonomi pendidikan, di daerah mengalami pasang-surut dan tantangan yang cukup signifikan dalam turut andil mempertanggungjawabkan kinerja sistem pendidikan nasional. Hasil penelitian Dauda (2004), misalnya dalam kerangka desentralisasi pemerintah daerah di Jinja, Uganda menunjukkan bahwa secara de facto penyediaan kesempatan layanan pendidikan dasar bagi masyarakat ternyata diperlukan bentuk pertanggungjawaban secara politis; terlebih ketika orangtua juga turut terlibat dalam penyediaan sumber daya pendidikan, pemerintah daerah juga dituntut harus ada kejelasan dalam memfasilitasi sumber daya dan tanggung jawabnya. Temuan ini hendaknya dapat diartikan bahwa peran daerah yang semakin luas dalam bidang pendidikan, di samping diperlukan kebijakan politis di tingkat pemerintah pusat dan pemerintah daerah yang lebih penting juga adalah adanya peta sumber daya dan mekanisme pertanggungjawaban pemberdayaannya.

Banyak faktor yang mempengaruhi keberhasilan otonomi pendidikan, seperti besarnya pendanaan daerah, kualifikasi ketenagaan (pendidik dan tenaga kependidikan) yang ada, pengembangan kurikulum yang memuat konten pembelajaran yang sesuai dengan karakteristik dan kebutuhan daerah, dan sumber daya pendukung lainnya. Kendala dalam penerapan otonomi pendidikan bagaikan mengurai benang kusut, terkadang menimbulkan stigma harus dari mana memulainya. Menurut Tim Pengembang Ilmu Pendidikan FIP-UPI (2011) implementasi dari regulasi tersebut menjadi kompleks dalam perkembangannya, lembaga-lembaga di daerah harus mengurusi penyelenggaraan pendidikannya sendiri, menentukan kadar kualitas sendiri yang berujung pada hasil pendidikan yang bervarian, sehingga perlu ditekankan untuk kemandirian penyelenggaraan pendidikan yang fokus pada upaya memelihara dan meningkatkan mutu pendidikan baik dalam skala lokal maupun skala nasional.

Di samping itu, konten dalam diversifikasi kurikulum juga menggambarkan ragam potensi yang terdapat di daerah, seperti kearifan lokal, budaya lokal, sumber daya alam, norma dan nilai-nilai yang memerlukan kesepakatan di tingkat daerah. Adanya rancangan pengembangan diversifikasi kurikulum diyakini akan menjadi salah satu unsur yang memberikan kontribusi yang cukup signifikan dalam mewujudkan proses berkembangnya kualitas potensi peserta didik agar peduli dengan konteks daerah. Diversifikasi kurikulum yang dikem- 
bangkan dengan berbasis pada potensi daerah sangat diperlukan sebagai instrumen untuk mengarahkan peserta didik menjadi warga negara yang memiliki standar di berbagai bidang kehidupan dalam rangka memudahkan peserta didik untuk menentukan kepastian apa yang harus dilakukan dan mengukur sejauh mana keberhasilan pencapaiannya.

Standar kualitas kehidupan bangsa secara nasional tentu saja dibangun berdasarkan analisis kebutuhan nasional dan daerah untuk membangun kehidupan bermasyarakat dan berbangsa serta kehidupan antarbangsa secara keseluruhan. Kualitas kehidupan suatu masyarakat di suatu daerah tentu saja ada persamaan dengan kualitas kehidupan berbangsa secara nasional tetapi juga memiliki kekhasan tertentu yang berbeda dari lingkungan masyarakat lainnya. Perbedaan-perbedaan itu merupakan faktor kekayaan nasional dan ketika dijadikan suatu karakter bangsa yang utuh dan dapat dituangkan ke dalam suatu diversifikasi kurikulum.

Pengembangan kurikulum dalam koridor diversifikasi pada gilirannya diharapkan dapat menghasilkan berbagai ragam kurikulum yang lebih sederhana, yang memiliki nilai relevansi dengan tuntutan dan kebutuhan serta kehidupan nyata peserta didik, masyarakat, pengembang daerah, dan jenjang pendidikan berikutnya. Bukan hanya hasil diversifikasi kurikulum yang penting, tetapi kemampuan mengembangkan pembaruan pendekatan pembelajaran untuk mengimple-mentasikan kurikulum yang terus menerus jauh lebih penting. Pemikiran tersebut dilandasi dan sejalan dengan hasil penelitian Ashley dan Jaap Vos (2015) yang menunjukkan bahwa model kurikulum yang sederhana yang telah dikembangkan daerah berhasil pula menerapakan model inovasi pembelajaran, walaupun kurikulum inti masih tetap diperlukan untuk dipelajari peserta didik, pengembang, dan perguruan tinggi. Temuan Ashley dan Jaap Vos tersebut sejalan dengan pernyataan Lubis (2011) bahwa kurikulum merupakan segala pengalaman dan kegiatan pembelajaran yang direncanakan dan diorganisir sedemikian rupa untuk peserta didik agar mencapai tujuan.

Di samping itu, penyusunan diversifikasi kurikulum selalu terkait pula dengan berbagai faktor, seperti perubahan-perubahan yang terjadi di masyarakat, kepemimpinan, iptek, politik kebudayaan nasional, dan tantangan kehidupan masa depan. Faktor tersebut selain menjadi faktor yang menyebabkan terjadinya perubahan kurikulum sekaligus menjadi landasan bagi pengembangan suatu diversifikasi kurikulum di daerah. Faktor kekuatan sosial dan kepemimpinan di daerah, misalnya yang berpengaruh terhadap kurikulum juga menyebabkan diversifikasi kurikulum tidak dapat membebaskan diri dari dinamika dan kekuatan politik di daerah bersangkutan. Hal ini sesuai dengan ungkapan bahwa curriculum is politically viable. Diversifikasi kurikulum baru dapat dinyatakan berlaku apabila sesuai dengan kemauan politik, dan oleh sebab itu suatu diversifikasi kurikulum khas daerah tidak dapat ditempatkan diri sepenuhnya sebagai suatu produk pendidikan di suatu daerah. Karena itu, perubahan kurikulum di setiap level kebijakan baik nasional maupun daerah dapat terjadi karena adanya perubahan kebijakan politik dan perubahan kekuatan sosial yang kemudian berwujud pada kebijakan publik yang sarat dengan nuansa politis.

Atas dasar latar belakang yang dikemukakan di atas, pertanyaan utama yang muncul adalah: "Bagaimana diversifikasi kurikulum di bumi Nusantara tercinta ini diwujudkan?". Apabila hal tersebut merupakan keniscayaan, pertanyaan berikutnya adalah: "Bagaimana diversifikasi kurikulum yang bersifat daerah itu secara konseptual dan kontekstual merupakan bagian yang tidak terpisahkan dari pengelolaan sistem pendidikan nasional secara keseluruhan?". Karena itu, artikel ini ingin memberi jawaban atas dua isu pokok yang dikemukakan. Harapannya, hasil kajian ini dapat menginspirasi pengembang diversifikasi kurikulum baik di pusat maupun di daerah. 
Artikel ini bertujuan untuk mengkaji khasanah pengembangan diversifikasi kurikulum ditinjau dari aspek desentralisasi pendidikan dengan fokus pada pemberian kewenangan yang lebih besar di tingkat daerah. Di mana kurikulum yang dikembangkan oleh daerah dapat dimaknai sebagai produk kebijakan publik di suatu daerah dalam khasanah diversifikasi kurikulum.

Dengan begitu, dapat dimaknakan bahwa diversifikasi kurikulum merupakan wujud kebijakan bagi daerah sebagai wahana menjabarkan lebih lanjut suatu kurikulum nasional dengan cara menyesuaikan, memperluas, dan memperdalam kompetensi serta bahan kajian pelajaran yang disesuaikan dengan kebutuhan, kemampuan, dan keadaan daerah serta sekolah. Diversifikasi kurikulum yang dikembangkan juga untuk melayani kebutuhan, minat dan bakat istimewa peserta didik serta bagi mereka yang memiliki kesulitan tertentu, seperti kelainan fisik, emosional, mental, sosial dan ekonomi dalam rangka layanan keberagaman penyelenggaraan sekolah.

\section{KAJIAN LITERATUR DAN PEMBAHASAN Kajian Literatur \\ Desentralisasi Pendidikan}

Pembahasan tentang desentralisasi pendidikan tidak bisa dilepaskan dari konsep kebijakan desentralisasi dan otonomi daerah. Pada awal tahun 2000-an makna desentralisasi dan otonomi daerah menjadi topik pembicaraan di mana-mana karena sebelumnya perbendaharaan kata itu jarang dipakai oleh berbagai kalangan di Indonesia. Makna desentraliasasi dan otonomi daerah telah menjadi keniscayaan dan menjadi semakin jelas seiring dengan diterbitkannya berbagai peraturan perundangundangan tentang otonomi daerah, seperti: 1) UURI No. 32 Tahun 2004 tentang Pemerintahan Daerah, 2) Perpu RI No. 3 Tahun 2005 tentang Perubahan atas UURI No. 32 Tahun 2004 tentang Pemerintahan Daerah, dan 3) UURI No. 12 Tahun 2008 tentang Perubahan Kedua atas UURI No. 32 Tahun 2004 tentang Pemerintahan Daerah (Republik Indonesia, 2005; Republik
Indonesia, 2006; Republik Indonesia, 2008). Dengan demikian, koridor makna desentralisasi menjadi tegas karena telah dilegitimasi oleh peraturan perundang-undangan yang berlaku.

Berdasarkan pada Pasal 1, butir 7 UndangUndang Republik Indonesia Nomor 32 Tahun 2004 tentang Pemerintahan Daerah, desentralisasi diartikan sebagai penyerahan kewenangan pemerintah oleh Pemerintah kepada Daerah Otonom dalam kerangka Negara Kesatuan Republik Indonesia (Republik Indonesia, 2005). Sementara menurut Hasbullah (2010) otonomi daerah diartikan sebagai penyerahan kewenangan urusan-urusan yang semula menjadi kewenangan pemerintah pusat kepada pemerintah daerah untuk melaksanakan urusanurusan yang semula menjadi urusan pemerintah pusat. Dengan demikian, dapat diartikan bahwa daerah dapat mengatur sendiri daerahnya sesuai dengan karakteristik dan kebutuhan serta sumber daya yang dimilikinya. Atau merujuk pendapat Nurcholis (2007) otonomi daerah adalah hak penduduk yang tinggal dalam suatu daerah untuk mengatur, mengurus, mengendalikan dan mengembangkan urusannya sendiri, termasuk pendidikan dengan menghormati peraturan perundang-undangan yang berlaku.

Otonomi daerah menurut Manan (2005) mempunyai dua arti: pertama, dalam arti formal diperlukan dalam rangka memperluas partisipasi masyarakat dalam pemerintahan. Kedua, dalam arti material mengadung makna sebagai usaha mewujudkan kesejahteraan dan sistem pemencaran kekuasaan menurut dasar negara berdasarkan atas hukum, yang menurut Sabarno (2008) tetap mengedepankan hakikat pembagian sumber daya alam yang wajar dan adil. Pemencaran kekuasaan dapat dimaknai sebagi keleluasaan daerah untuk menyelenggarakan pemerintahan yang mencakup kewenangan semua bidang pemerintahan kecuali kewenangan di bidang politik luar negeri, pertahanan keamanan, peradilan, moneter dan fiskal, agama serta kewenangan bidang lainnya yang akan ditetapkan tersendiri. Kebijakan otonomi daerah sebagai akibat desentralisasi tersebut membawa 
konsekuensi besar pada tata kelola berbagai bidang, termasuk pendidikan. Dalam kaitanya dengan perubahan peran ini, satuan kerja di tingkat kabupaten/kota perlu mengembangkan kapasitas merumuskan kebijakan operasional maupun kebijakan yang menjadi wewenangnya. Salah satu dari kebijakan yang dimaksud adalah dalam bidang pendidikan.

Otonomi daerah bukan berarti semua urusan rumah tangga daerah otonom dalam berbagai sektor dapat dilakukan secara otonom, tetapi yang urgen di sini terdapat pergeseran kebijakan berkait sebagian besar urusan yang semula ditangani dengan sistem sentralisasi bergeser ke desentralisasi. Sementara itu, otonomi pendidikan menurut Isjoni (2006) merupakan dampak dari otonomi daerah, dan ini berarti peran dan tanggung jawab pengelolaan dan pelaksanaan pendidikan telah diserahkan kepada pemerintah daerah, termasuk tanggung jawab dalam meningkatkan mutu pendidikan lewat sebuah kurikulum.

Dengan demikian, dapat dikatakan bahwa desentralisasi pendidikan merupakan salah satu paradigma baru bentuk perkembangan dari kebijakan pemerintah tentang pengelolaan pendidikan yang menurut pendapat Tilaar (2006) mempunyai dua tuntutan, yaitu 1) akuntabilitas terhadap masyarakat sebagai pemiliknya, dan 2) di dalam hidup bersama sebagai satu bangsa maka pendidikan juga mempunyai fungsi di dalam pengembangan bangsa Indonesia. Dari dua pendapat tersebut di atas dapat ditarik benang merah bahwa otonomi pendidikan melalui koridor desentralisasi pendidikan diharapkan mampu meningkatkan layanan dan mutu pendidikan. Meminjam istilah Widjaja (2007) otonomi bertujuan pada peningkatan kesejahteraan rakyat.

\section{Diversifikasi Kurikulum}

Khusus sektor pendidikan dalam era desentralisasi menimbulkan pendapat pro dan kontra, pendapat Ilyasin dan Nurhayati (2012), misalnya menyatakan bahwa otonomi pendidikan dan paradigma baru pendidikan mengantarkan lembaga pendidikan pada arah baru dengan perubahan pada fenomena penataan kembali sistem pendidikan nasional yang sentralistik menuju pada suatu sistem yang memberikan kesempatan luas kepada inisiatif masyarakat setempat, bahkan pengelolaan pendidikan yang semula berpusat pada pemerintahan pusat mulai dari yang bersifat mikro, meso, maupun makro beralih pada pengelolaan pendidikan pada pola manajemen lembaga pendidikan di mana lembaga pendidikan tersebut berada yang lebih dikenal dengan istilah otonomi daerah.

Pernyataan tersebut dapat dimaknai bahwa otonomi pendidikan sebagai hak mengatur dan memerintah sendiri bidang pendidikan yang ada di daerahnya. Sedangkan desentralisasi pendidikan merupakan pelimpahan alat dari pemerintah kepada pemerintah daerah untuk mencapai tujuan layanan pendidikan yang lebih baik dan sekaligus menciptakan proses pengambilan keputusan yang lebih demokratis. Namun, pelimpahan kewenangan tersebut tidak semudah yang dibayangkan. Kajian yang dilakukan oleh West, Anne, Allmendinger, Nikolai, Barham (2010) menyatakan bahwa desentralisasi di bidang pendidikan adalah multifaset dan kompleks, karena bisa bermakna berbagai jenis desentralisasi kehidupan bersama yang dipengaruhi oleh perbedaan politik, kebijakan, dan konteks sosial ekonomi dengan hasil pendidikan yang bisa berbeda. Di samping itu, merujuk pendapat Hasbullah (2010) efektivitas pelayanan pendidikan pada tingkat akar rumput (grass root) juga penting untuk mendorong partisipasi aktif masyarakat dalam pembangunan pendidikan. Dengan begitu maka pemberdayaan seluruh pemangku kepentingan pendidikan di daerah menjadi lebih optimal termasuk dalam konteks diversifikasi kurikulum.

Diversifikasi menurut Kamus Besar Bahasa Indonesia merupakan padanan kata dari penganekaragaman (Departemen Pendidikan Nasional, 2005). Dalam konteks diversifikasi kurikulum, berarti penganekaragaman/ pembedaan kurikulum di setiap daerah tetapi koridornya tetap mengacu pada kurikulum 
standar nasional. Dengan demikian dapat dimaknai bahwa aneka ragam kurikulum yang dimaksud adalah bahwa bahan kajian/ kompetensi, materi pembelajaran, pendekatan pembelajaran, dan pendekatan penilaian yang terdapat dalam konsep kurikulum nasional dapat dijabarkan, diperkaya, dan ditambah atau dimodifikasi dan disesuaikan dengan keadaan, karakteristik dan kebutuhan daerah, peserta didik atau sekolah.

Diversifikasi kurikulum dalam konteks penulisan artikel ini ialah bagaimana kurikulum nasional tersebut harus dikembangkan lebih rinci agar sesuai dengan tuntutan kebutuhan daerah. Isi kurikulum hendaknya mencerminkan apa yang hendak diinginkan oleh daerahnya terhadap pendidikan yang dibangunnya. Karenanya, potensi sumber daya manusia, budaya dan pranata sosial yang ada turut membentuk nilainilai dan sekaligus menjadi tujuan pendidikan di daerah. Sedangkan dalam konteks karakteristik peserta didik dapat dilihat dari berbagai aspek yang menyangkut seperti kemauan atau minat, bakat serta kemampuan, latar belakang sosial ekonomi, dan budaya yang dianutnya. Sementara konteks satuan pendidikan dapat dilihat dari sudut pandang sumber daya yang dimiliki, dan lokasi. Dengan demikian dapat dikatakan bahwa diversifikasi kurikulum adalah aktivitas penyusunan kurikulum di daerah atau sekolah dengan cara menjabarkan, memperkaya, memperdalam, menambah, memperluas, dan memodifikasi kurikulum nasional karena adanya keragaman karakteristik daerah. Berdasarkan telaahan di atas, diversifikasi kurikulum dalam kerangka desentraliasasi pendidikan dalam artikel ini adalah pendelegasian pemerintah atas hak, wewenang dan kewajiban kepada daerah otonom dalam sektor pendidikan, yang dalam hal ini fokus pada pengembangan keanekaragaman kurikulum pendidikan yang berciri khas daerah. Pendelegasian yang dimaksud, yakni pemberian otoritas kepada pemerintah daerah, baik tingkat provinsi maupun kabupaten/kota untuk mengurus sendiri pengembangan dan penyusunan keragaman kurikulum yang di- sesuikan dengan keadaan, karakteristik dan kebutuhannya tetapi tetap mengacu pada kurikulum nasional.

\section{Pembahasan}

Sebagaimana konstruk yang dirancang di atas bahwa kajian ilmiah ini akan mengetengahkan diversifikasi kurikulum, maka pembahasan dibatasi pada diversifikasi kurikulum khusus jalur pendidikan formal untuk pendidikan dasar dan pendidikan menengah. Oleh karena itu, pembahasan pada bagian berikut mengacu pada dimensi tersebut.

\section{Produk Diversifikasi Kurikulum}

Dalam UURI Nomor 20 Tahun 2003 tentang Sisdiknas secara eksplisit terdapat dua pasal yang mengatur tentang konten kurikulum, yaitu Pasal 36 dan 37. Pada Pasal 36, Ayat (3) dinyatakan bahwa kurikulum disusun sesuai dengan jenjang pendidikan dalam kerangka Negara Kesatuan Republik Indonesia dengan memperhatikan paling tidak sepuluh dimensi ranah kajian, yakni 1) peningkatan iman dan takwa; 2) peningkatan akhlak mulia; 3) peningkatan potensi, kecerdasan, dan minat peserta didik; 4) keragaman potensi daerah dan lingkungan; 5) tuntutan pembangunan daerah dan nasional; 6) tuntutan dunia kerja; 7) perkembangan ilmu pengetahuan, teknologi, dan seni; 8) agama; 9) dinamika perkembangan global; dan 10) persatuan nasional dan nilainilai kebangsaan.

Rumusan kata "dengan memperhatikan" dari ketentuan peraturan perundang-undangan tersebut mengandung makna bahwa kurikulum jenjang pendidikan dasar dan menengah haruslah sebuah rancangan yang sarat dengan norma, nilai, pengetahuan dan keterampilan yang dapat meningkatkan kemampuan, mutu kehidupan dan martabat manusia Indonesia terdidik yang beriman dan bertakwa kepada Tuhan Yang Maha Esa, berakhlak mulia, sehat, berilmu, cakap dan cerdas, kreatif, mandiri, demokratis dan bertanggung untuk menjawab tantangan zaman yang selalu berubah. Dalam 
upaya memenuhi harapan dari tuntutan kurikulum semacam itu maka penyempurnaan pola pikir dan penguatan tata kelola kurikulum serta pendalaman dan perluasan materi, di samping dapat dilakukan secara sentralisasi (nasional) dapat pula dilakukan dengan model diversifikasi kurikulum. Sementara itu, pengembangan kurikulum menurut Organization for Economic Cooperation and Development (OECD) (dalam Burki, Shahid, Perry dan Dillinger 1999) merupakan tipologi kewenangan pendidikan yang dapat dijabarkan/didiversifikasikan, dan didesentralisasikan.

Kerangka pikir semacam itu, dan kaitannya dengan masalah pengembangan/penyusunan diversifikasi kurikulum dilakukan di daerah dalam kerangka pengembangan dan pelaksanaan pendidikan nasional, kiranya perlu memperhatikan regulasi yang ada, yakni bahwa salah satu ketentuan dalam UURI Nomor 20 Tahun 2003 tentang Sisdiknas, Pasal 4, Ayat (6) dinyatakan bahwa pendidikan diselenggarakan dengan memberdayakan semua komponen masyarakat melalui peran serta dalam penyelenggaraan dan pengendalian mutu layanan pendidikan (Republik Indonesia, 2003). Ketentuan ini memberi makna bahwa pada dasarnya pengembangan diversifikasi kurikulum juga bisa merupakan tanggung jawab bersama antara masyarakat, pemerintah daerah, dan pemerintah pusat. Apabila prinsip ini dianut, berarti bahwa keberhasilan pengembangan diversifikasi kurikulum di daerah, dapat diukur dari sisi naik turunnya mutu pendidikan secara keseluruhan adalah benar-benar tanggung jawab bersama ketiga sentra pendidikan tersebut. Karena itu, kemauan secara politis baik dari pemerintah pusat maupun pemerintah daerah menjadi penting agar informasi yang merupakan prasyarat bagi partisipasi politik masyarakat pendidikan menjadi lebih jelas dan terbuka.

Pola pelimpahan wewenang pemerintah pusat ke pemerintah daerah tersebut diperkuat hasil penelitian Yan (2014) yang menemukan bahwa sangat penting untuk mengubah cara pandang pelaku pendidikan di daerah. Misalnya, penilaian berbasis Gaokao yang dilakukan guru bahasa Inggris di China Tengah sebagai pelaksana reformasi kurikulum guna mencapai keselarasan antara visi kebijakan pendidikan di era reformasi kurikulum dan realitas praktik guru di tingkat akar rumput (daerah). Penilaian tersebut muncul karena adanya kesenjangan implementasi antara kebutuhan kurikulum baru dan kemampuan praktik guru di kelas, meskipun secara umum dukungan terhadap guru dari tujuan kurikulum baru secara pedagogi cukup baik, serangkaian kendala yang saling terkait secara kontekstual, seperti tantangan profesional dan psikologis yang cukup besar untuk guru, peserta didik yang resisten, kurangnya dukungan sekolah, kendala fisik sekolah, dan yang paling penting adalah budaya penghargaan timbal balik yang kurang lazim di masyarakat China turut berperan.

Setelah lima belas tahun kebijakan desentralisasi digulirkan barangkali diperlukan perluasan dan penambahan peran pemerintah daerah, khususnya pada sektor pendidikan khususnya kurikulum pendidikan, lebih spesifik lagi dalam pengembangan diversifikasi kurikulum yang sesuai dengan karakteristik, kebutuhan, dan potensi daerah. Implikasi dari kebijakan semacam ini berarti bahwa sebagian besar mutu hasil pendidikan nantinya adalah hasil pengaruh proses desentralisasi pendidikan di daerah. Bisa jadi selama ini karena adanya distorsi kebijakan, dan belum menggeliatnya pemberdayaan seluruh potensi pemangku kepentingan pendidikan di daerah barangkali adalah juga merupakan faktor-faktor yang memungkinkan kurang berhasilnya bidang pendidikan di daerah bersangkutan. Asumsi dasar yang dikemukakan tersebut diperkuat hasil penelitian Reyes-García, Victoria, Vadez, Aragón, Huanca, dan Jagger (2010) yang menemukan bahwa sembilan tahun setelah berlalunya undang-undang desentralisasi, pengetahuan tentang reformasi tersebut hanya sebagian kecil yang bisa mencapai daerah Tsimane. Masyarakat yang hidup di kota dan dekat kota memiliki akses layanan pendidikan lebih banyak, dan partisipasi mereka dalam 
ekonomi pasar juga lebih banyak, hal itu menunjukkan bahwa kesadaran akan pentingnya desentralisasi masih belum merata.

Selanjutnya, ketentuan Pasal 37, Ayat (1) dalam UURI Nomor 20 Tahun 2003 tentang Sisdiknas (Republik Indonesia, 2003) bahwa kurikulum pendidikan dasar dan menengah wajib memuat sepuluh bahan kajian, yaitu: 1) pendidikan agama; 2) pendidikan kewarganegaraan; 3) bahasa; 4) matematika; 5) ilmu pengetahuan alam; 6) ilmu pengetahuan sosial; 7) seni dan budaya; 8) pendidikan jasmani dan olahraga; 9) keterampilan/kejuruan; dan 10) muatan lokal. Kaidah tersebut berlaku bagi proses pengembangan kurikulum untuk semua jenis dan jenjang pendidikan. Berangkat dari gambaran ketentuan tersebut berarti bahwa diversifikasi kurikulum yang akan dikembangkan paling tidak harus memuat 10 bidang kajian (mata pelajaran) inti yang nantinya akan dikuasai peserta didik yang ada di seluruh wilayah hukum Republik Indonesia.

Dari kutipan di atas dapat ditarik makna bahwa diversifikasi kurikulum untuk jalur pendidikan formal mengandung paling sedikit sepuluh bahan kajian yang merupakan konten dari kurikulum yang mengarahkan peserta didik pada jenjang pendidikan dasar dan menengah agar memperoleh panduan dan bimbingan dalam memperoleh pengalaman belajar sehingga peserta didik dapat menggali, memahami, menghargai dan melakukan sesuatu sebagai hasil belajar yang dilaksanakan. Pengalaman belajar peserta didik yang merupakan wujud pembelajaran pada kurikulum dapat dikembangkan dalam k onteks nasional, dan dapat pula dikembangkan dalam konteks daerah. Secara skematis diversifikasi kurikulum yang dapat dikembangkan dengan kekhasan daerah disajikan pada Tabel 1.

Dari Tabel 1 nampak bahwa apa pun bahan kajian maupun aspek-aspek bahan kajian yang terdapat dalam kurikulum nasional (dalam tabel penulis sebut sebagai aspek kemampuan), esensi kontennya dapat di-diversifikasi di tingkat daerah. Implikasi dari itu maka pengembangan diversifikasi kurikulum di suatu daerah, misalnya jangan hanya sekadar kumpulan daftar mata pelajaran semata yang dituntut di dalam suatu jenis, jenjang pendidikan, dan satuan pendidikan tetapi juga lebih luas dari itu, yakni berisi konten-konten bersifat selektif, adaftif dan kreatif yang sesuai dengan kebutuhan dan karakteristik daerah.

Premis tersebut sejalan dengan kajian Pinto (2014) dalam menganalisis partisipasi warga pada pengembangan kebijakan kurikulum selama akhir 1990-an. Di mana Pinto menemukan bahwa warga pada sejumlah daerah di Ontario diberi peluang untuk meningkatkan peran sertanya dalam proses pengembangan kebijakan kurikulum pendidikan formal dengan cara mendorong pembelajaran, dialog, pemberdayaan, kesetaraan, dan semangat kebersamaan. Studi ini mengindiksikan bahwa pendekatan pengembangan kurikulum di suatu daerah hendaknya menganut norma-norma pokok sekitar kebutuhan peserta didik, dan dari problema-problema yang dihadapi peserta didik dalam kehidupannya.

Hasil dari pengembangan diversifikasi kurikulum dapat pula dimaknai sebagai kurikulum muatan lokal. Di mana isi dari suatu rencana pembelajaran tersebut dikaitkan dengan lingkungan alam, lingkungan sosial, dan lingkungan budaya serta kebutuhan daerah. Dalam konteks kurikulum seperti itu, Nasir (2013) memberi istilah pada kurikulum yang dikembangkan daerah ke dalam dua bentuk, yaitu bersifat melekat ke seluruh mata pelajaran dan berupa kegiatan tersendiri yang tidak ada kaitannya dengan mata pelajaran. Kegiatan tersendiri dapat diartikan sebagai mata pelajaran yang berdiri sendiri.

Dari dua pemikiran tersebut di atas, pertanyaanya adalah kapan dan sampai seberapa jauh daerah akan diberi kewenangan yang lebih besar oleh pemerintah pusat dalam menentukan desain diversifikasi kurikulum. Hal tersebut patut dikemukakan karena berdasarkan pengalaman penulis memfasilitasi pembentukan, memberikan bantuan teknis pengembangan 
Tabel 1 Bahan Kajian dalam Konteks Kurikulum Daerah

\begin{tabular}{lllll}
\hline No & Bahan Kajian & Aspek Kemampuan & \multicolumn{2}{l}{ Jabaran Diversifikasi Kurikulum } \\
\hline 1 & Pendidikan & 1. Al-Quran & Absolut & \\
& Agama Islam & 2. Keimanan & Memberi & contoh keteladanan karena keyakinan
\end{tabular}
dalam hati, diucapkan dengan lisan, dan diwujudkan dengan tingkah-laku.

3. Akhlak Menginternalisasikan pendidikan budi pekerti (kepada Tuhan, diri sendiri, sesama, orang tua, dan lingkungan)

4. Ibadah/Fiqih Memahami dan menerapkan hukum-hukum yang menjadi acuan bagi perbuatan seseorang, dalam bentuk wajib, sunnah, haram, makruh dan mubah yang diselaraskan dengan lingkungan.

5. Tarikh Absolut

$2 \quad \begin{aligned} & \text { Pendidikan } \\ & \text { Kewarganegaraan }\end{aligned}$
Kewarganegaraan

2. Peraturan, Norma, dan Hukum

3. Hak Asasi Manusia

4. Kebutuhan Warga Negara

5. Konstitusi

6. Kekuasaan dan Politik

7. Masyarakat Demokratis

8. Nilai-nilai Pancasila

9. Globalisasi
1. Mendengarkan

2. Berbicara

3. Membaca

4. Menulis

5. Kebahasaan

6. Apresiasi Sastra

$4 \quad$ Matematika

Menerapkan prinsip Bhineka Tunggal Ika,
nasionalisme, kebebasan yang bertanggung jawab, wawasan nusantara, dan pembangunan daerah.

Menerapkan peraturan, norma, dan hukum yang berlaku di daerah.

Menerapkan prinsip hak asasi universal dan hak asasi khas daerah.

Menerapkan kebutuhan warga daerah dalam konteks sosial, ekonomi, politik, dan budaya.

Menerapkan konstitusi negara baik secara nasional maupun konstitusi produk daerah.

Memahami peran partai politik dan mekanisme kekuasaan di daerah.

Menerapkan hak dan kewajiban sebagai warga negara di suatu daerah.

Menerapkan, menghayati dan mengamalkan nilainilai Pancasila dalam kehidupan di daerah.

Memahami dan menerapkan perkembangan, tuntutan dan kebutuhan zaman dalam konteks daerah di era global.

Mendengarkan dan mengidentifikasi unsur cerita rakyat yang sarat bermuatan kearifan lokal.

Dengan topik khas kedaerahan: pembicara, topik, forum, penyimak, dan tanggapan.

Sajian tulisan/karangan khas daerah untuk dipahami, diterima, ditolak, dibandingkan, dianalisis, diyakini, diterapkan.

Membuat karya tulis yang efektif tentang khas daerah dengan segala perniknya.

Penggunaan kode-kode kebahasaan yang dianggap sopan dan santun, biasa saja, dan yang dianggap kaku dan kasar dalam setiap pertuturan oleh komunitas antarwarga di daerah.

Mengapresiasi karya sastra khas daerah baik secara instrinsik/dari dalam maupun ekstrinsik/dari luar.

Menggunakan bahan kajian, media, dan substansi bahasan dengan konteks daerah.

Menggunakan bahan kajian, media, dan substansi bahasan dengan konteks daerah.

Menggunakan bahan kajian, media, dan substansi bahasan dengan konteks daerah.

Menggunakan bahan kajian, media, dan substansi bahasan dengan konteks daerah.

Menggunakan bahan kajian, media, dan substansi bahasan dengan konteks daerah.

Menggunakan bahan kajian, media, dan substansi bahasan dengan konteks daerah.

Menggunakan bahan kajian, media, dan substansi bahasan dengan konteks daerah.

Menggunakan bahan kajian, media, dan substansi bahasan dengan konteks daerah. 


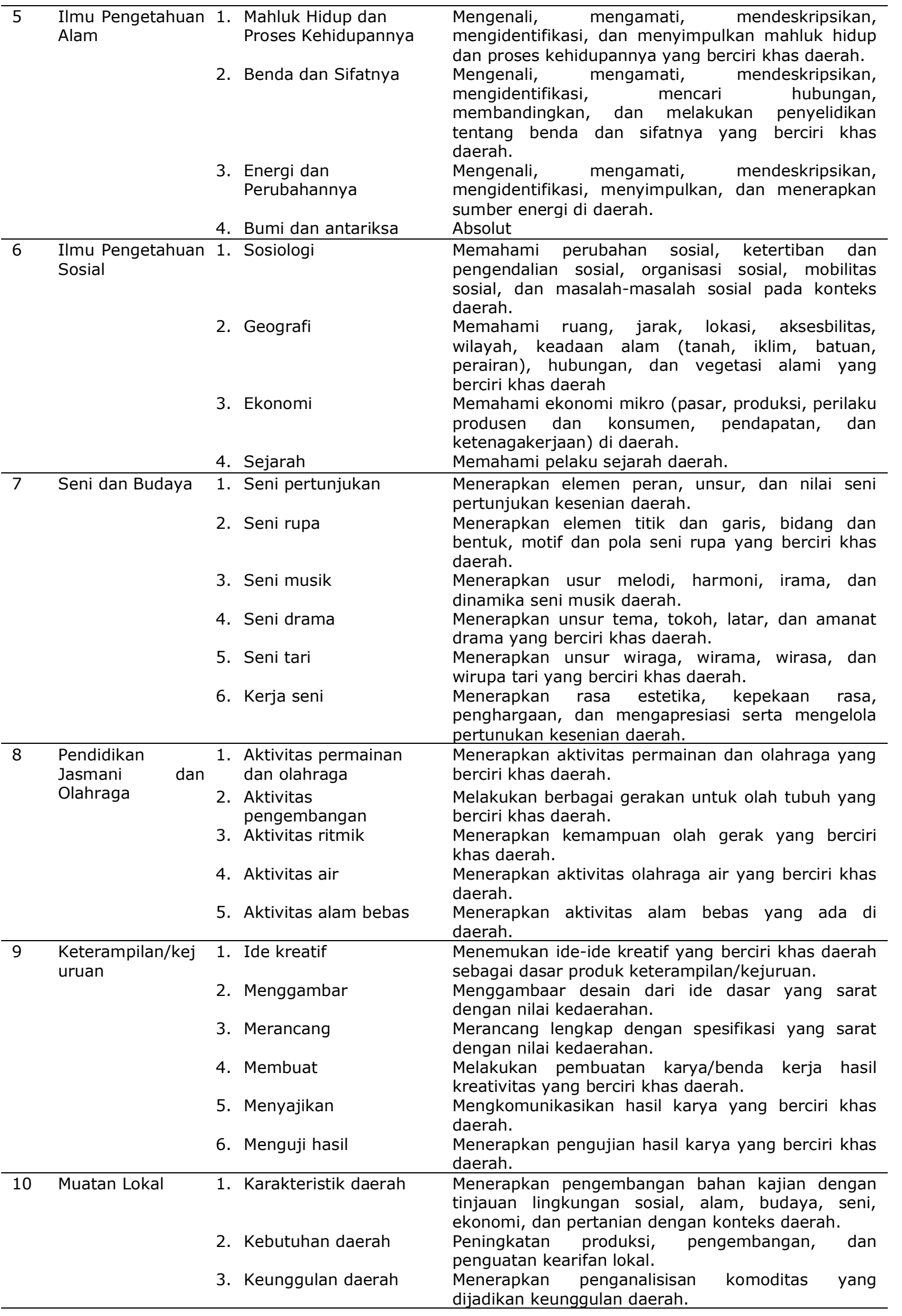

Sumber: Kurikulum Berbasis Kompetensi, Kurikulum dan Hasil Belajar, Puskur (2002) 
kurikulum, dan pendampingan penyusunan kurikulum kepada TPK daerah sejak tahun 2000an hingga kini nampak belum memberikan dampak yang signifikan. Bahkan, dapat dikatakan jalan di tempat.

\section{Produk Pemberdayaan Tim Pengembang}

Dalam pengembangan suatu diversifikasi kurikulum, pemberdayaan TPK daerah memiliki posisi penting, sisi yang lain profesionalitas mereka juga penting. Oleh karena itu, untuk mendukung upaya mewujudkan pengembangan diversifikasi kurikulum daerah dan menjadikan muatan daerah juga sekaligus sebagai wadah internalisasi keberadaban dan pembudayaan masyarakat pembelajar di daerah maka implikasi yang perlu dilakukan daerah adalah merancang berbagai program terobosan secara terus menerus kepada berbagai pemangku kepentingan pendidikan, terutama guru di daerah yang nantinya berperan sebagi pengembang diversifikasi kurikulum.

Pelibatan guru dalam mengembangkan diversifikasi kurikulum menurut Law, Edmond, Galton, dan Wan (2010) sering tidak sejalan dengan kebijakannya. Birokrasi yang kompleks, prosedur yang rumit telah menghambat diversifikasi kurikulum. Di samping itu, tuntutan akan penguasaan guru terkait dengan teori pendidikan dan landasan empiris menjadi prasyarat utama yang harus dipenuhi dalam mengembangkan diversifikasi kurikulum dianggap berlebihan. Temuan ini mengisyaratkan bahwa apabila daerah diberi pelimpahan kewenangan untuk mengembangkan diversifikasi kurikulum, satu hal yang penting diperhatikan adalah profesionalisme tim pengembang dan manajemen tim harus akuntabel. Satu sisi, sumber daya manusia pengembang diversifikasi kurikulum di daerah mempunyai peranan yang sangat penting. Pada sisi yang lain, kebijakan daerah yang dapat merangsang motivasi dan kinerja mereka baik berupa material maupun nonmaterial juga tak kalah pentingnya.

Selama ini, pengalaman daerah dalam pengembangan kurikulum muatan lokal untuk pendidikan dasar dan menengah yang mengandalkan TPK daerah, misalnya dapat dijadikan pelajaran yang berharga dan menjadi inspirasi untuk diadopsi atau diadaptasi bagi daerah untuk mengembangkan diversifikasi kurikulum khas daerah. Pada kenyataannya kemampuan profesional TPK daerah dalam pengembangan diversifikasi kurikulum masih ada kendala. Masalah kinerja TPK daerah yang secara faktual terjadi hampir pada semua daerah menunjukkan gejala yang tidak merata tingkat profesionalitasnya. Hasil bincang-bincang yang penulis lakukan dengan beberapa pimpinan daerah sekitar bulan Oktober tahun 2014 menunjukkan adanya kekhawatiran bagi sebagian TPK daerah manakala mereka harus melakukan pengembangan kurikulum khas daerah. Selebritas memfasilitasi pengembangan kurikulum yang sesuai dengan keadaan dan kebutuhan daerah masih belum menjiwai setiap TPK daerah. Untuk sementara baru sebatas diprogramkan tanpa makna.

Pengembangan diversifikasi kurikulum yang disesuaikan dengan kebutuhan, potensi, dan kondisi daerah maupun sekolah merupakan kebijakan nasional memerlukan penerjemahan dari pihak daerah maupun sekolah tentang mau ke mana pendidikan di daerahnya. Kemampuan untuk menerjemahkan hal ini sehingga menjadi diversifikasi kurikulum khas daerah harus dijawab dengan mengembangkan sumber daya / potensi daerah. Pengembangan sumber daya yang merupakan kesiapan daerah dalam mengembangkan dan mengelola diversifikasi kurikulum, diperlukan adanya wadah bagi peningkatan kemampuan TPK daerah yang secara sistemik harus diwujudkan. Tim ini bukan hanya dituntut mampu melakukan penyusunan diversifikasi kurikulum semata, melainkan yang lebih penting lagi yakni mampu melakukan pengembangan diversifikasi kurikulum secara terus menerus sesuai siklus pengembangan kurikulum, yaitu perancangan, pelaksanaan, dan evaluasi.

Oleh sebab itu, dalam ranah diversifikasi kurikulum ini, pemerintah pusat seyogyanya 
mencari terobosan dan membuat regulasi yang memungkinkan daerah merasa perlu mencari model terbaik berbentuk satuan tugas, lembaga atau badan yang mewadahi tenaga pengembangnya. Penelitian Gessler dan Ashmawy (2014) menyimpulkan bahwa desentralisasi politik memerlukan penciptaan badan-badan terpilih melalui berbagai pemangku kepentingan yang terlibat dalam proses pengambilan keputusan, dan bahwa sekolah mampu discretionally merencanakan tujuan dan sasaran kurikulum mereka sendiri. Hasil studi ini maknanya adalah manakala daerah diberi kesempatan dan peluang untuk mengembangkan diversifikasi kurikulum, satu hal yang harus diperhatikan adalah kemampuan profesional tim pengembangnya yang juga secara organisatoris harus juga dikelola secara profesional.

Sejalan dengan isu tersebut, kemampuan profesional pendidik/guru yang direkrut dalam mengembangkan diversifikasi kurikulum daerah dapat ditingkatkan secara terus menerus melalui berbagai program/kegiatan seperti pelatihan, workshop kurikulum, dan sebagainya yang difasilitasi oleh pemerintah pusat bersama-sama dengan pemerintah daerah. Peningkatan kapasitas tim pengembang penting, tetapi yang lebih penting dari pada itu adalah dilema kemampuan pengembang untuk mengorgnisasi konten diversifikasi kurikulum yang disesuaikan dengan kebutuhan, kondisi, situasi, serta karakteristik sosial budaya daerah, yang dilengkapi dengan pengembangan perangkat lainnya seperti konsep pendekatan pembelajaran, pendekatan penilaian, dan sumber belajar yang diperlukan dalam kurikulum daerah yang masih perlu peningkatan.

Berkait dengan dinamika daerah, merujuk hasil penelitian Yin, Hongbiao, Chi-Lee, dan Wang (2014) menunjukkan bahwa individu yang memimpin perubahan reformasi kurikulum ditempatkan dalam 'Trilemma' yang timbul dari tiga nilai-nilai budaya yang saling bertentangan, yaitu budaya kepatuhan, budaya pemeriksaan, dan budaya pedagogik baru yang dianjurkan oleh reformasi. Dari studi ini nampak jelas bahwa tim pengembang diversifikasi kurikulum daerah yang relatif independen, memiliki otoritas berdasarkan kepakarannya. Demikian pula penelitian Tihanyi, Laszlo, Ellstrand, Daily, dan Dalton (2000) yang menemukan bahwa pentingnya komposisi tim manajemen pengembang dalam keputusan melaksanakan kebijakan diversifikasi kurikulum. Tim manajemen tersebut hendaknya berasal dari beragam latar keahlian mengingat kehadiran sebuah kurikulum memiliki peran multifungsi, bagi guru, kepala sekolah, pengawas, peserta didik, orang tua, dan masyarakat.

Di samping itu, untuk pengembangan diversifikasi kurikulum, banyak kebijakan yang bisa diberlakukan, di antaranya upaya menata tenaga TPK daerah yang lebih profesional, mendorong pendidikan dan pelatihan dalam konteks penyusunan kurikulum, dan meningkatkan jumlah personalnya. Implikasi dari pemikiran yang melatarbelakangi ide pengembangan diversifikasi kurikulum daerah sebagaimana diungkap di atas mesti pula diikuti penyediaan berbagai standar indikator keberhasilan secara nasional berkait dengan berbagai komponen kurikulum di setiap daerah. Regulasi tentang hal itu sudah menjadi keharusan karena akan mengendalikan tuntutan kualitas pendidikan nasional secara keseluruhan, dan karenanya mutlak untuk diwujudkan. Dengan adanya tolok ukur yang standar untuk pengendalian mutu diversifikasi kurikulum, jelas akan membuat kepastian bagi setiap orang dalam mencapai keunggulan pendidikan di setiap daerah yang hendak diraihnya. Merujuk pendapat Ravitch (1995), standar merupakan sebuah "tujuan" (apa yang harus dilakukan) dan "ukuran" kemajuan ke arah tujuan itu (seberapa baik hal itu dilakukan). Artinya, diversifikasi kurikulum yang dikembangkan di daerah, mesti memperlihatkan standar arah yang jelas bahwa kurikulum yang dikembangkan tersebut telah mempedulikan aspek-aspek potensi manusia yang terkait dengan domain afektif, misalnya, 
mengutip desain Kurikulum 2013 untuk pengembangan soft-skils yang seimbang dengan hard-skills (Hasan, 2013).

Demikian pula rancangan kurikulum yang diterapkan untuk pengembangan diversifikasi kurikulum yang berciri khas daerah berdampak harus didasarkan pada pengertian bahwa kurikulum adalah suatu konstruk pendidikan yang utuh untuk jenjang pendidikan dasar dan menengah. Rancangan pemikiran ini menempatkan jabaran mata pelajaran atau bahan kajian dalam diversifikasi kurikulum daerah sebagai organisasi konten kurikulum yang terbuka dan saling berinteraksi mesti ditata secara baik oleh TPK. Dengan begitu, implikasi dari rancangan diversifikasi kurikulum yang akan digunakan untuk mengembangkan kurikulum daerah harus mampu memberikan keterkaitan antarkonten kurikulum baik yang bersifat horizontal maupun vertikal. Secara analitik hubungan antarkonten diversifikasi kurikulum dapat ditunjukkan betapa faktor bahan kajian tersebut mempengaruhi ide, desain, implementasi dan evaluasinya bagi tim pengembang diversifikasi kurikulum.

Filosofi pengembangan diversifikasi kurikulum seperti itu, diperkuat oleh studi López (2007) yang menyimpulkan bahwa selain kerangka konseptual diversifikasi kurikulum, diversifikasi kelas, keanekaragaman peserta didik dan kapasitas guru turut berpengaruh dalam pengembangan konten kurikulum. Demikian pula implikasi dari paradigma diversifikasi kurikulum yang diusulkan manajemen daerah untuk pengembangan lebih lanjut, kebijakan, dan pengimplementasiannya juga turut berkontribusi pada isi kurikulum. Di mana kontribusi pada tindakan-tindakan pembaruan dalam bidang kurikulum dan pembelajaran pada gilirannya dianggap memecahkan salah satu masalah pendidikan dengan cara pemberdayaan sumber daya daerah. Konstruk tersebut diperkuat hasil studi Sutjipto (2011) bahwa strategi pemberdayaan pengembang kurikulum sangat berpengaruh terhadap capaian keberhasilan pengembangan kurikulum di daerah.Dari gambaran di atas tampak betapa penataan alur pengembangan diversifikasi kurikulum daerah implikasinya juga harus didasarkan pada konsep curriculum development, di mana keseluruhan dimensi kurikulum, yaitu ide, desain, implementasi dan evaluasi kurikulum mesti direncanakan dalam satu kesatuan oleh TPK daerah. Konsep curriculum development menghendaki suatu tim yang sejak awal mengedepankan pemberdayaan dalam merancang pengembangan ide kurikulum (curriculum idea), dokumen kurikulum (curriculum construction), implementasi kurikulum (curriculum implementation), dan evaluasi kurikulum (curriculum evaluation) dalam suatu desain utuh (grand design) yang sejalan dengan kebijakan daerah sekaligus senafas dengan kebijakan pendidikan nasional.

Dengan kebijakan seperti itu, yang hakiki adalah bahwa para pengembang dan penyusun diversifikasi kurikulum daerah pertama-tama harus mendalami hakikat tujuan pendidikan nasional dan kemudian mencoba menerjemahkan ke dalam tingkatan-tingkatan tertentu sesuai dengan kekhasan daerah sebagaimana model pada Tabel 1. Ini berarti bahwa pema-haman yang mendalam tentang pemberdayaan segala sumber daya daerah, dan gambaran yang jelas tentang tuntutan kehidupan masyarakat di masa depan adalah dimensi kedua yang harus dijadikan kerangka acuan dalam perencanaan diversifikasi kurikulum yang berciri khas suatu daerah.

Faktor-faktor di atas itu penting karena diversifikasi kurikulum sebagai dokumen tertulis adalah rancangan mengenai kualitas yang akan dimiliki peserta didik di manapun mereka berada. Di mana sistem kurikulum tersebut adalah satusatunya unsur sistem pendidikan yang dapat direncanakan dan dikendalikan untuk mengembangkan potensi diri. Ini tidak lain karena sistem pendidikan tidak dapat secara langsung mengatur lingkungan, latar belakang sosialekonomi, dan kemampuan dasar. Sementara konten yang dipelajari untuk menguasai kualitas yang dirumuskan dalam tujuan, proses/ pengalaman belajar yang diperlukan untuk menguasai konten, dan asesmen hasil belajar 
untuk membantu peserta didik mencapai tingkat kemampuan yang dipersyaratkan merupakan hasil pendidikan masa depan.

Pola pikir demikian merupakan salah satu jalan yang bisa ditempuh, namun diversifikasi kurikulum tentunya tidak menghendaki adanya pengotakan hasil pendidikan secara regional tetapi standar hasil yang setara di mana pun peserta didik berada. Kedudukan strategik daerah dengan sistem diversifikasi kurikulumnya memang belum pernah terjadi di negeri tercinta ini bila kembali mengingat bahwa tangung jawab utama penyiapan rancangan kurikulum selama ini ada di pemerintah. Oleh karena itu, diversifikasi kurikulum bisa berujud dikarenakan adanya permasalahan dan dijadikan solusi untuk memecahkan permasalahan tersebut.

Pemahaman pengembangan diversifikasi kurikulum di daerah tentang hakikat fungsi dan tujuan pendidikan serta tugas setiap jenjang pendidikan ke depan tidak dapat dipungkirinya. Pendidikan yang sesuai dengan kebutuhan masa depan hanya akan dapat terwujud apabila terjadi pergeseran atau perubahan pola pikir dengan kesertaan khas daerah. Laporan Badan Standar Nasional Pendidikan tahun 2010 (BSNP, 2010) menegaskan bahwa untuk meningkatkan kualitas pendidikan dalam menghadapi masa depan perlu dilakukan perubahan paradigma pembelajaran melalui pergeseran tata cara penyelenggaraan kegiatan pendidikan dan pembelajaran di dalam kelas atau lingkungan sekitar lembaga pendidikan tempat peserta didik menimba ilmu, salah satu di antaranya ialah bahwa rancangan diversifikasi kurikulum daerah mesti memperhatikan pergeseran pembelajaran dari produksi massa menuju kebutuhan pelanggan/daerah. Implikasi pemikiran semacam ini adalah jika kurikulum sebelumnya didesain untuk semua peserta didik tanpa kecuali memperoleh bahan atau konten materi yang sama, maka diversifikasi kurikulum yang akan datang perlu mengakomodasi kebutuhan berbeda setiap peserta didik pada setiap daerah untuk mendapatkan konten sesuai dengan ketertarikan atau keunikan potensi yang dimilikinya.
Untuk melaksanakan peranan pemerintah daerah dalam diversifikasi kurikulum dalam sistem pendidikan nasional yang bersifat masal perlu diikuti dengan rancangan mengenai regulasi berkait dengan proses dan hasil pengembangan diversifikasi kurikulum dimaksud. Di masa mendatang hal itu amat diperlukan agar terdapat kejelasan pengaturan dalam pengembangan diversifikasi kurikulum di tingkat daerah yang sekaligus digunakan sebagai akuntabilitas kinerja tim pengembang terkait dengan diversifikasi kurikulum diketahui secara transparan oleh masyarakat. Perangkat pendukung yang dimaksud juga bagian yang tak terpisahkan dari pengembangan kurikulum (curriculum development) yang terdiversifikasi dan merupakan tindak lanjut dari konstruksi dokumen kurikulum (curriculum construction). Dengan turut melaksanakan kaidah ini berarti bahwa indikator dari tercapainya tujuan diversifikasi kurikulum kalau dilihat pada sektor pendidikan dapat dinyatakan bahwa daerah turut menyumbangkan hasil mencerdaskan kehidupan bangsa kepada negara menjadi signifikan karena memperoleh kesempatan yang lebih luas.

Salah satu kesempatan yang dapat dipetik dari kebijakan diversifikasi kurikulum adalah adanya kemampuan peserta didik dalam bidang kebahasaan, kesastraan, atau pengajaran bahasa dan sastra yang dapat mengangkat budaya dan kearifan lokal. Dengan pendekatan pembelajaran seperti itu, peserta didik secara langsung melakukan praktik kemampuan berbahasa sehingga mereka akan memiliki pengetahuan, sikap, kepercayaan, kesenian, moral, hukum, adat-istiadat, dan kemampuankemampuan lain yang berciri kedaerahan yang didapat sebagai warga bangsa. Praktik kemampuan berbahasa seperti ini sejalan dengan studi kasus terhadap tujuh guru yang mengembangkan kurikulum pembelajaran sendiri sebagai model interaktif, dan proses kontekstual yang dilakukan oleh Wette (2009). Studi ini mengidentifikasi prinsip-prinsip penyusunan kurikulum daerah, dan praktik pembelajaran 
yang umum dilaksanakan oleh sejumlah guru bahasa, sehingga berkontribusi terhadap kemampuan berbahasa peserta didik dengan cara penerapan pembelajaran model berbasis praktik yang berciri lingkungan.Prinsip apa pun kebijakan diversifikasi kurikulum, satu hal yang tetap harus dijadikan komitmen semua pemangku kepentingan pendidikan di daerah bahwa pengembangan diversifikasi kurikulum berciri khas daerah memang dimungkinkan untuk bisa diwujudkan, namun konten diversifikasi kurikulum betapa pun ragamnya harus tetap mempertimbangkan dan mengutamakan kepentingan nasional sebagaimana yang diamanatkan dalam peraturan perundangundangan yang berlaku dengan mengingat bahwa keberadaan kurikulum akan menjadi instrumen persatuan bangsa dalam wilayah Negara Kesatuan Republik Indonesia.

Bahkan, Brennan (2011) penyusunan kurikulum nasional di Australia yang dilakukan pada tahun 2011 merupakan sinyal pergeseran paradigma pemerintahan yang cukup signifikan mengingat lebih dari 25 tahun negara tersebut memakai kurikulum federal yang dikembangkan dalam konteks federalisasi. Dengan demikian, dalam mewujudkan diver-sifikasi kurikulum baik di tingkat daerah maupun sekolah ke depan, pemikirannya adalah meru-pakan sesuatu hal yang mungkin lazim, tetapi senantiasa tetap selaras dengan ketentuan dalam UndangUndang Republik Indonesia Nomor 20 Tahun 2003 tentang Sistem Pendidikan Nasional. Alfred dan Carter (1995), mengatakan bahwa visi dan idealisme itu haruslah tetap merujuk dan bersumber pada paham ideologi nasional, yang dianut oleh seluruh komponen bangsa.Akhirnya, diversifikasi kurikulum yang diwacanakan ini berkait dengan pengembangan kurikulum yang berciri khas daerah yang mencakup dokumen kurikulum, implementasi kurikulum, dan evaluasi kurikulum sangat mungkin bisa diwujudkan dengan model pemberdayaan seluruh pemangku kepentingan pendidikan di daerah. Karena itu, diversifikasi kurikulum menjadi alternatif kebijakan yang harus dilakukan. Akan tetapi yang lebih penting, satu sisi adalah tim pengembang diversifikasi kurikulum harus memahami bahwa esensi pengembangan kurikulum harus memiliki berbagai landasan terutama landasan yuridis, filosofis dan teoritis, guna menetapkan ide diversifikasi kurikulum untuk menjawab tantangan yang dihadapi, mengembangkan desain dokumen kurikulum, mengembangkan rancangan untuk implementasi kurikulum, dan mengembangkan rancangan evaluasi kurikulum.

Pada sisi yang lain, hasil diversifikasi kurikulum harus mampu meningkatkan kualitas sumber daya manusia, pertumbuhan ekonomi yang berkelanjutan, terwujudnya masyarakat sejahtera, mempunyai kemampuan mengelola teknologi, mempunyai keunggulan komparatif yang tinggi, dan menjamin keberlangsungan hidup berbangsa dan bernegara. Dengan koridor semacam itu, maka keseriusan dalam pengembangan diversifikasi kurikulum di daerah hendaknya dapat dijadikan salah satu indikator keberhasilan peningkatan mutu pendidikan. Meminjam istilah Soedijarto (2008) sebagai upaya pengelolaan pendidikan yang baik di daerah yang mampu memenuhi standar nasional yang ditetapkan dan memperkokoh rasa kebangsaan.

\section{Produk Sosial dari Diversifikasi Kurikulum}

Apakah yang membuat suatu diversifikasi kurikulum menjadi penting? Mengapa diversifikasi kurikulum tidak merupakan faktor penggerak kebijakan yang cukup? Salah satu jawabannya mungkin adalah esensi kehadiran dokumen kurikulum yang terwujud dalam bentuk perihal latar belakang, landasan filosofis dan teoretik kurikulum, desain kurikulum, proses pembelajaran, penilaian hasil belajar dan implementasi kurikulum. Ketaatan seluruh pengembangan suatu kurikulum terhadap norma-norma, aturan positif, prosedur, dan pada mekanisme teknis yang terbakukan, perubahan-perubahan yang terjadi di masyarakat, kepemimpinan, dan tantangan kehidupan masa depan menjadi vital karena paling tidak terdapat lima alasan berikut. 
Pertama, adanya diversifikasi kurikulum setidaknya memudahkan tindakan-tindakan untuk membimbing peserta didik berkontribusi terhadap lingkungannya dan menjadi bagian dari masyarakat itu. Peserta didik dalam bangunan institusi satuan pendidikan yang kondusif tidak hanya memiliki visi dan misi yang dijajakan pada masa pembelajaran. Ia juga tidak sekadar mampu memperoleh pengetahuan setelah menyelesaikan pendidikannya. Tidak kalah pentingnya, ia juga harus mampu menggerakkan energi positifnya untuk membangun kebutuhankebutuhan masyarakatnya, dan keutuhan bangsanya. Meminjam istilah Gadjong (2007) bahwa salah satu prinsip pelimpahan wewenang kepada daerah otonom adalah dapat menjamin hubungan yang serasi antara pemerintah pusat dengan pemerintah daerah atas dasar keutuhan negara kesatuan.

Kedua, dalam era desentralisasi pendidikan, sebenarnya terbuka peluang besar untuk mengembangkan diversifikasi kurikulum pendidikan di daerah menjadi lebih berkualitas. Hal ini terjadi karena kepala daerah memiliki kewenangan yang penuh dalam menentukan kualitas pendidikan sesuai dengan konteks daerahnya. Jadi, dalam era desentralisasi pendidikan, kualitas pendidikan untuk masa yang akan datang lebih banyak tergantung pada komitmen daerah untuk merumuskan visi dan misi di daerahnya. Jika daerah cukup visioner, pengembangan diversifikasi kurikulum akan memiliki peluang yang besar untuk dapat memenuhi standar kualitas pendidikan sesuai dengan harapan para pemangku kepentingan. Manakala pemerintah daerah memiliki kemauan politik (political will) yang kuat dan kemudian disertai dengan kebijakan dan sistem perencanaan pengembangan diversifikasi kurikulum yang mengedepankan arti penting pendidikan sebagai upaya human investment di daerah, dapat dipastikan pendidikan di daerah itu akan memiliki praksis yang baik, dan kualitas pendidikan akan dapat ditingkatkan.

Ketiga, model diversifikasi kurikulum yang dikembangkannya setidaknya juga merefleksikan kepercayaan (trust) masyarakat/publik. Dalam hal ini substansi dari kepercayaan itu terletak pada harapan tentang hari esok berkait dengan lingkungannya. Seseorang yang yakin bahwa sesuatu akan terjadi pada hari esok dan bahwa sesuatu yang terjadi pada hari esok itu akan lebih baik daripada hari ini adalah seseorang yang memiliki kepercayaan. Tentu saja situasi sebaliknya akan terjadi jika kepercayaan hilang atau mengalami penguapan. Namun, kepercayaan bukan pula sesuatu yang terjadi dengan sendirinya. Kepercayaan harus memiliki basis empirik dan berlandaskan pada karya nyata. Persyaratan yang berbasis empirik dengan karya inilah yang membuat produk sebuah model diversifikasi kurikulum menjadi sangat penting. Ketidakjelasan tentang aturan main pengembangan model diversifikasi kurikulum adalah indikasi adanya persoalan perancangan yang pada gilirannya akan mengikis kepercayaan masyarakat itu. Intinya, mengembangkan model diversifikasi kurikulum adalah suatu kegiatan untuk menyemai kepercayaan kepada pemangku kepentingan pendidikan yang selalu berakar pada budaya bangsa, kehidupan masa kini dan berorientasi kepada kehidupan masa depan.

Keempat, model diversifikasi kurikulum yang dikembangkannya adalah jalan keluar untuk mengatasi jebakan keterasingan peserta didik terhadap lingkungannya. Setiap peserta didik memiliki keunikan sendiri. Setiap peserta didik memiliki perbedaan satu dengan lainnya. Latar belakang sosial, budaya dan kepentingan ekonomi yang berbeda ini mengharuskan hadirnya suatu mekanisme diversifikasi kurikulum pembelajaran yang menggambarkan terpenuhinya tingkat kemampuan berpikir peserta didik terhadap kompleksitas masyarakatnya. Mengutip pendapat Nuh (Kompas, 2014) kalau seseorang dihadapkan pada persoalan, pola pikirnya how to solve the problem, itu pertanda sudah well educated. Namun, kalau pola pikirnya how to create the new problem, dia belum well educated (bukan mencari solusi terhadap persoalan, melainkan persoalannya yang dipersoalkan). 
Kelima, desain implementasi diversifikasi kurikulum memiliki posisi yang sangat menentukan bagi keberhasilan suatu kurikulum sebagai rencana tertulis. Beauchamp (1975) mengartikan implementasi kurikulum sebagai "a process of putting the curriculum to work". Pendapat tersebut dapat dimaknai bahwa implementasi kurikulum merupakan rencana tertulis ke dalam bentuk nyata di kelas, yaitu terjadinya proses transmisi dan transformasi segenap pengalaman belajar peserta didik. Diimplementasikannya diversifikasi kurikulum bukan sekadar diukur dari tersedia dan disusunnya rencana pelaksanaan pembelajaran (RPP) oleh pihak pengembang, melainkan juga seberapa jauh efektivitas pembelajaran di kelas memiliki beberapa kebaruan yang mengarah pada kemajuan dan penanaman karakter bangsa. Penelitian Nurohman (2011) menemukan bahwa antusiasme masyarakat, serta lingkungan sekolah yang kondusif dan strategis merupakan faktor eksternal yang berkontribusi cukup signifikan terhadap pencapaian mutu pendidikan atas upaya pelaksanaan kurikulum tingkat satuan pendidikan (KTSP).

Dengan adanya diversifikasi kurikulum yang berintikan khas daerah sekaligus menggambarkan bahwa praksis pendidikan seperti itu akan mendorong peserta didik berhasrat belajar karena kegiatannya mengasyikkan dan tidak membosankan, dan juga sekaligus merefleksikan "kepentingan bersama" dalam mengarungi kehidupan nyata, sehingga mereka tidak merasa asing dengan sekitarnya. Dengan demikian, maka sumber daya daerah menjadi lebih bermakna karena terejawantahkan dalam kurikulum khas untuk mereka. Pendekatan seperti ini pernah direkomendasikan oleh Papanastasiou (2012) pada saat terjadi kebijakan reformasi kurikulum nasional di Inggris bahwa dalam ruang kebijakan pendidikan Eropa apabila teknologi tata kelola produksi pengetahuan yang diatur dalam sebuah kurikulum tidak memperhatikan konteks kekhasan 'Eropa' maka budaya yang ada berisiko hilang ke dalam dominasi paradigma pengetahuan global.
Hampir tidak mungkin membayangkan jika setiap peserta didik dalam suatu entitas pendidikan yang disebut sekolah yang tersebar di seluruh pelosok tanah air menjalankan mekanismenya sendiri untuk memperjuangkan kepentingannya. Karena ketidakmungkinan seperti itulah diperlukan satuan tugas pengembang diversifikasi kurikulum. Karena itu pula hasil pengembangan diversifikasi kurikulum dari kelompok TPK daerah menjadi sangat penting. Kurikulum tersebut memberikan rujukan bagaimana setiap satuan pendidikan yang tersebar seluruh daerah itu berperilaku secara absah tanpa harus menafikan betapa substansialnya kepentingan diversifikasi kurikulum pendidikan. Tim pengembang kurikulum di daerah ringkasnya adalah ibarat pisau untuk memajukan kepentingan pendidikan di daerahnya melalui pengembangan kurikulum secara terus-menerus sesuai siklus pengembangan kurikulum, yaitu penyusunan, pelaksanaan, dan evaluasi.

Pada sisi yang lain, dengan tugas dan peranan sebagai tim pengembang diversifikasi kurikulum yang berciri khas daerah berarti bahwa TPK daerah sendiri tidak akan dapat melaksanakan tugasnya secara sempurna. Faktor utama yang merupakan masalah dalam pelaksanaan tugas pengembangan diversifikasi kurikulum daerah saat ini adalah regulasi sebagai payung hukum yang memuat rincian tugas, hak, kewajiban dan tugas pokoknya. Persoalan hukum ini harus ada kemauan politis dari semua pihak karena menyangkut berbagai peraturan perundang-undangan mulai dari undang-undang, peraturan pemerintah, keputusan menteri, peraturan daerah, hingga surat keputusan yang juga merupakan turunan dari peraturan yang lebih tinggi.

Apabila kesemua persyaratan di atas telah terpenuhi, maka pemberdayaan TPK daerah guna mengembangkan diversifikasi kurikulum dan mengawal pengimplementasiannya yang berciri khas daerah merupakan bagian dari pekerjaan sehari-hari dari sistem manajerial mereka. Oleh karena itu, di samping faktor regulasi dan 
kemauan politis dari pengambil kebijakan mulai dari tingkat pusat hingga daerah, yang perlu dirancang pula ialah yang melatarbelakangi pemberdayaan TPK daerah, bagaimana prosesnya, serta segala sesuatu yang berhubungan dengan pemberdayaan TPK daerah itu sebagai organisasi sendiri dalam pengembangan suatu kurikulum. Kemudian, dengan pengelolaan sumber daya manusia yang profesional akan dapat diwujudkan model diversifikasi kurikulum yang berciri khas daerah yang efektif sebagai modal perubahan. Semangat diversifikasi kurikulum tersebut sejalan dengan hasil temuan Razzaq dan Forde (2013) bahwa sistem pendidikan di Pakistan berkait dengan reformasi kurikulum dan sistem penilaian mampu mendorong kepala sekolah berinisiasi melakukan perubahan.

Pada khasanah pengembangan diversifikasi kurikulum, pemberdayaan TPK daerah memiliki makna bahwa pemberdayaan TPK daerah tidak hanya mengembangkan potensi kompetensi TPK daerah, tetapi juga harkat dan martabat, rasa percaya diri dan harga dirinya, dan terpeliharanya tatanan nilai sosial budaya institusi lembaga di daerah turut berkembang. Pemberdayaan sebagai konsep sosial budaya yang implementatif dalam bekerja yang berpusat pada TPK daerah, tidak saja menumbuhkan dan mengembangkan nilai kinerja, tetapi juga nilai tambah sosial dan nilai tambah budaya. Menurut O'Brien (2015), di Inggris pemahaman yang benar tentang nilai budaya adalah mustahil tanpa disiplin ilmu lain, baik ilmu sosial pemerintah, dan ilmu humaniora pada pendidikan tinggi. Di sisi lain, pemberdayaan berdasarkan perspektif ilmu-ilmu sosial merupakan proses menampilkan peran-peran aktif dan kolaboratif antara TPK daerah dan mitranya. Hal ini secara paradoks juga memberdayakan sistem lain, atau secara paternalistik melimpahkan kekuatan (power) kepada orang lain yang juga berarti memberdayakan mereka.

\section{SIMPULAN DAN SARAN Simpulan}

Berdasarkan pembahasan di atas dapat disimpulkan beberapa hal. Pertama, dari sisi peraturan perundang-undangan yang berlaku terdapat ketentuan yang mengikat semua pihak bahwa daerah dimungkinkan dapat berperan dalam pengembangan diversifikasi kurikulum yang disesuaikan dengan karakteristik, kebutuhan dan potensinya. Kedua, konten diversifikasi kurikulum dapat dimulai dari ide, perancangan, implementasi dan evaluasi kurikulum yang cakupannya mulai dari penataan struktur, pemilihan bahan kajian yang esensial baik secara utuh maupun merupakan penjabaran dari standar yang ada. Ketiga, dengan memandang bidang pekerjaan pengembangan diversifikasi kurikulum sebagai wilayah garapan yang tidak sederhana diperlukan tenaga pengembang yang profesional, yang berarti tim tidak mungkin bekerja sendiri agar tugas-tugas tim menjadi lebih memadai, efisien, dan efektif. Keempat, dari kesiapan sumber daya manusia daerah dianggap cukup berpengalaman dalam mengembangkan diversifikasi kurikulum. Kelima, bahwa diversifikasi kurikulum masih memerlukan beragam regulasi dan kemauan politis dari pemangku kepentingan pendidikan mulai dari pusat hingga daerah sebagai dasar bagi tim pengembang kurikulum (TPK) untuk melaksanakan tugasnya. Dengan demikian, studi ini menyimpulkan bahwa diversifikasi kurikulum merupakan kebijakan yang telah diberlakukan untuk mendorong keberagaman berkembang secara terus menerus tanpa menafikan tujuan pendidikan nasional.

\section{Saran}

Dari hasil pembahasan dan simpulan di atas tampak bahwa diversifikasi kurikulum memungkinkan dapat dilakukan oleh pihak daerah otonom karena adanya desentralisasi pendidikan, namun kenyataan yang ada menunjukkan bahwa kemauan politik tentang hal itu masih belum sekuat bidang-bidang lain. Oleh karena itu, pertama, para pengambil kebijakan baik dari 
pihak legislatif, yudikatif maupun eksekutif mulai dari tingkat pusat, provinsi, hingga daerah kabupaten/kota hendaknya memiliki kepedulian untuk meng-hasilkan regulasi berkait diversifikasi kurikulum. Kedua, keberadaan sumber daya manusia (tim pengembang kurikulum) di daerah dipandang amat strategis dalam mengawal kebijakan diversifikasi kurikulum ataupun yang lain, untuk itu daerah hendaknya menyediakan program pendidikan dan pelatihan yang berkelanjutan yang memadukan kemampuan akademik dan praktik pengembangan secara imajinatif, kreatif, dan inovatif. Ketiga, apapun jenis pekerjaan yang dilakukan oleh TPK sangat diperlukan kesadarannya bahwa era sekarang ini sistem kerja yang ditawarkan dunia adalah dari pribadi menuju berbasis tim. Keempat, dalam mengangkat konten diversifikasi kurikulum tim pengembang kurikulum hendaknya melakukan analisis konteks, seminar, workshop, dan kajian dalam bentuk lain untuk menemukan ruh kekhasan daerah. Kelima, pelaksanaan pengembangan diversifikasi kurikulum daerah, masalah yang krusial adalah ketepatan/ kebenaran konten dalam perancangannya, oleh karena itu diperlukan pendampingan/mentoring agar secara konseptual dan kontekstual merupakan bagian yang tidak terpisahkan dari pengelolaan sistem pendidikan nasional.

\section{PUSTAKA ACUAN}

Alfred, R. L. \& Carter, P. 1995. Building the Future: Comprehensive Educational Master Planning Report 1995-2005. Alabama: University of Alabama \& Community College Consortium.

Ashley, A. J, \& Jaap V. 2015. The Department as a Third Sector Planner: Implementing Civic Capacity through the Planning Core Curriculum. Journal of Planning Education and Research, 0739456X15591281, July 9, 2015.

Badan Standar Nasional Pendidikan. 2010. Laporan BSNP Tahun 2010. Jakarta: BSNP.

Beauchamp, G. 1975. Curriculum Theory. Willmette, Illionis: The Kagg Press.

Brennan, M. 2011. National Curriculum: A Political-Educational Tangle. Australian Journal of Education, 55(3), h/m. 259-280.

Burki, S. J., Guillermo E. P. \& William R. D. 1999. Beyond the Center: Decentralizing the State. The World Bank, Washington D.C.

Dauda, C. L. 2004. The Importance of De Facto Decentralization in Primary Education in SubSaharan Africa PTAs and Local Accountability in Uganda. Journal of Planning Education and Research, 24(1), h/m. 28-40.

Departemen Pendidikan Nasional. 2005. Kamus Besar Bahasa Indonesia, Edisi Ketiga. Jakarta: Balai Pustaka.

Departemen Pendidikan Nasional. 2002. Kurikulum Berbasis Kompetensi: Kurikulum dan Hasil Belajar. Jakarta: Pusat Kurikulum, Balitbang Depdiknas.

Gadjong, A.A. 2007. Pemerintahan Daerah: Kajian Politik dan Hukum. Bogor: Ghalia Indonesia.

Gessler, M. \& Ashmawy, I. K. 2014. The Effect of Political Decentralization on School Leadership in German Vocational Schools. Educational Management Administration \& Leadership, 1741143214549967, December 9, 2014.

Hasan, S. H. 2013. Kecenderungan dan Perubahan Pola Pikir untuk Memahami Kurikulum 2013. Makalah Disampaikan dalam Pembekalan Pelatih Nasional Kurikulum 2013 di Grand Topic Hotel. Jakarta: Kemdikbud. 
Hasbullah. 2010. Otonomi Pendidikan: Kebijakan Otonomi Daerah dan Implikasinya terhadap Penyelenggaraan Pendidikan. Jakarta: PT Raja Grafindo Persada.

Ilyasin, M \& Nurhayati, N. 2012. Manajemen Pendidikan. Yogyakarta: Aditya Media Publishing. Isjoni. 2006. Membangun Visi Bersama; Aspek-aspek Penting dalam Reformasi Pendidikan. Jakarta: Yayasan Obor Indonesia.

Law, E., Galton, M., \& Wan, S. 2010. Distributed Curriculum Leadership in Action: A Hong Kong Case Study. Educational Management Administration \& Leadership, 38(3), hlm. 286-303.

López, O. S. 2007. Classroom Diversification: A Strategic View of Educational Productivity. Review of Educational Research, 77(1), hlm. 28-80.

Lubis, M. S. 2011. Telaah Kurikulum. Bandung: Citapustaka Media Perintis.

Manan, B. 2005. Menyongsong Fajar Otonomi Daerah. Cetakan pertama. Yogyakarta: Pusat Studi Hukum Fakultas Hukum UII.

Nasir, M. 2013. Pengembangan Kurikulum Muatan Lokal dalam Konteks Pendidikan Islam di Madrasah. Hunafa: Jurnal Studia Islamika, 10(1), hlm. 1-18.

Nuh, M. 2014. Lampu Masyarakat Terdidik. Kompas. 23 September 2014. Hal. 6.

Nurcholis, H. 2007. Teori dan Praktik Pemerintahan dan Otonomi Daerah. Jakarta: PT Grasindo.

Nurohman. 2011. Efektivitas Pelaksanaan Kurikulum Tingkat Satuan Pendidikan (KTSP) dalam Upaya Pencapaian Mutu Pendidikan di MTs Annur Karangjunti Losari Brebes (Suatu Studi Analisis Pelaksanaan KTSP di MTs Annur Karangjunti, Kecamatan Losari, Kabupaten Brebes). Tesis. Program Pascasarjana Institut Agama Islam Negeri (IAIN) Syekh Nurjati, Cirebon.

O'Brien, D. 2015. Cultural Value, Measurement and Policy Making. Arts and Humanities in Higher Education, 14(1), h/m. 79-94.

Papanastasiou, N. 2012. Comparison as Curriculum Governance: Dynamics of the European-Wide Governance Technology of Comparison within England's National Curriculum Reforms. European Educational Research Journal, 11(3), h/m. 413-427.

Pinto, L. E. 2014. Learning through Civic Participation: Policy Actors' Perspectives on Curriculum Reform Involvement in Ontario. Policy Futures in Education, 12(3), hlm. 403-416.

Ravitch, D. 1995. National Standards in American Education. Washington DC: Brooking Institution Press.

Razzaq, J., \& Forde, C. 2013. The Impact of Educational Change on School Leaders: Experiences of Pakistani School Leaders. Educational Management Administration \& Leadership, 41(1), h/m.63-78.

Republik Indonesia. 2003. Undang-Undang Republik Indonesia Nomor 20 tentang Sistem Pendidikan Nasional. Jakarta: Departemen Pendidikan Nasional.

Republik Indonesia. 2005. Undang-Undang Republik Indonesia Nomor 32 Tahun 2004 tentang Pemerintahan Daerah. Jakarta: Ditjen Otda.

Republik Indonesia. 2006. Perpu Republik Indonesia Nomor 3 Tahun 2005 tentang Perubahan atas Undang-Undang Republik Indonesia Nomor 32 Tahun 2004 tentang Pemerintahan Daerah. Jakarta: Ditjen Otda.

Republik Indonesia. 2008. Undang-Undang Republik Indonesia Nomor 12 Tahun 2008 tentang Perubahan Kedua Atas Undang-Undang Republik Indonesia Nomor 32 Tahun 2004 tentang 
Pemerintahan Daerah. Jakarta: Tamita Utama.

Reyes-García, V., Vadez, V., Aragón, J., Huanca, T., \& Jagger, P.A. 2010. The Uneven Reach of Decentralization: A Case Study among Indigenous Peoples in the Bolivian Amazon. International Political Science Review, 31(2), hlm. 229-243.

Soedijarto. 2008. Landasan dan Arah Pendidikan Nasional Kita. Jakarta: Buku Kompas.

Sabarno, H. 2008. Memandu Otonomi Daerah Menjaga Kesatuan Bangsa. Jakarta: Sinar Grafika.

Sutjipto. 2011. Bantuan Teknis Profesional Pengembangan Kurikulum kepada Tim Pengembang Kurikulum Daerah sebagai Wahana Pemberdayaan Staf Pusat Kurikulum. Jurnal Pendidikan dan Kebudayaan, 17(3), hlm. 338-354.

Tihanyi, L., Ellstrand, A. E., Daily, C. M., \& Dalton, D. R. 2000. Composition of the Top Management Team and Firm International Diversification. Journal of Management, 26(6), h/m. 1157-1177.

Tilaar, H.A.R. 2006. Standarisasi Pendidikan Nasional: Suatu Tinjauan Kritis. Jakarta: Rineka Cipta.

Tim Pengembang Ilmu Pendidikan FIP-UPI. 2011. Ilmu dan Aplikasi Pendidikan. Bandung: Grasindo.

West, A., Allmendinger, J., Nikolai, R., \& Barham, E. 2010. Decentralisation and Educational Achievement in Germany and the UK. Environment and Planning C: Government and Policy, 28(3), h/m. 450-468.

Wette, R. 2009. Making the Instructional Curriculum as an Interactive Contextualized Process: Case Studies of Seven ESOL Teachers, Language Teaching Research, 13(4), h/m. 337365.

Widjaja, H.A.W. 2007. Penyelenggaraan Otonomi Daerah di Indonesia. Jakarta: PT Raja Grafindo Persada.

Yan, C. 2014. We Can't Change Much Unless The Exams Change: Teachers' Dilemmas in The Curriculum Reform in China. Improving Schools, 18(1), hlm. 5-69.

Yin, H., Lee, J.C.K., \& Wang, W. 2014 Dilemmas of Leading National Curriculum Reform in a Global Era: A Chinese Perspective. Educational Management Administration \& Leadership, 42(2), hlm. 293-311. 